All patients were nursed in isolation and no secondary cases occurred. The klebsiella strains showed resistance to cefotaxime and aztreonam, and up to five further classes of antibiotics. Resistance to third-generation cephalosporins was successfully transferred to Escherichia coli J62 from the $K$ pneumoniae strains from the first two cases, consistent with these ESBLs being plasmid-mediated; and plasmids of 60 and $70 \mathrm{MD}$, respectively, were found on agarose gel electrophoresis.

These three cases illustrate the possible origins of organisms producing ESBLs-namely, international transfer with the patient, inter-hospital transfer, and selection of the resistant strain within a hospital. Nosocomial outbreaks of ESBL-producing Enterobacteriaceae with multiple resistance ${ }^{2}$ to a range of antibiotic classes have occurred in Europe ${ }^{3,4}$ and the USA. ${ }^{5}$ The continued use of third-generation cephalosporins exerts substantial selection pressure in favour of ESBL-producing organisms and also for the evolution ${ }^{6}$ of ESBLs. This, together with the introduction of similar oral cephalosporins, such as cefixime, into the community, should prompt laboratory surveillance for such strains. We suggest a variation of the double-disc synergy test ${ }^{3}$ on isolates showing moderate resistance to cefotaxime. Should the use of thirdgeneration cephalosporins be restricted??

We thank Dr T. L. Pitt, Central Public Health Laboratory, for serotyping the isolates, and Prof J. M. T. Hamilton-Miller and Dr S. H. Gillespie for advice and comments.

$\begin{array}{ll}\text { Department of Medical Microbıology, } & \text { A. A. MACDONALD } \\ \begin{array}{l}\text { Royal Free Hospital, } \\ \text { London NW3 2OG, UK }\end{array} & \text { P. A. C. MAPLE } \\ \text { Divisıon of Hospital Infection, } & \text { C. C. KIBBLER } \\ \text { Central Public Health Laboratory, } & \\ \text { London NW9 } & \text { R. C. GEORGE } \\ & \text { A. P. JOHNSON } \\ \text { Department of Medical Microbıology, } & \text { S. K. DU BOIS } \\ \text { Edinburgh University Medical School } & \text { S. G. B. AMYES }\end{array}$

1 BSAC Workıng Party. In-vitro antibıtic sensitivity testing. $f$ Antzmacrob Chemother 1988; 21: 701-10.

2. Jacoby AJ, Sutton S. Propertes of plasmids responsible for production of extended-spectrum beta-lactamases. Antimarob Agents Chemother 1991; 35: $164-69$.

3. Sirot J, Chanal C, Pett A, Sirot D, Labıa R, Gerband G. Klebszella pneumonae and other enterobacteriaceae producing novel plasmid-mediated beta-lactamases markedly active against third-generation cephalosporins: epıdemıologic studies. Rev Infect Dis 1988; 10: 850-59.

4. Brun-Buisson C, Legrand P, Phillipon A, Montravers P, Ansquer M, Duval J. Transferable enzymatic resistance to third generation cephalosporins durng a nosocomial outbreak of Klebsiella pneumomiae. Lancet 1987; ii: 302-06.

5. Rice LB, Willey SH, Papanicolaou GA, et al. Outbreak of ceftazidime resistance caused by extended-spectrum beta-lactamases at a Massachusetts chronic-care facility. Antimucrob Agents Chemother 1991; 34: 2193-99.

6. Collatz E, Labia R, Gutmann L. Molecular evolution of ubiqutous beta-lactamases towards extended-spectrum enzymes actve against newer beta-lactam antibiotics. Mol Microbrol 1990; 4: 1615-20.

7. Payne DJ, Amyes SGB. Transferable resistance to extended-spectrum beta-lactams: a major threat or a minor inconvenience? f Antimacrob Chemother 1991;27:255-61.

\section{In-vivo monitoring of neuronal loss in Creutzfeldt-Jakob disease by proton magnetic resonance spectroscopy}

SIR, - The advent of bovine spongiform encephalopathy has renewed interest in novel approaches to the clinical diagnosis of spongiform encephalopathies such as Creutzfeldt-Jakob disease (CJD). We have seen a case of sporadic CJD where the only magnetic resonance imaging abnormalities were mild cortical atrophy and hyperintensities in the lentiform nuclei, as noted previously. ${ }^{1}$ By contrast, proton magnetic resonance spectroscopy (MRS) demonstrated significant metabolic alterations in cortical grey matter and white matter and in striatum. Right frontal lobe biopsy, done 2 days after these scans, revealed fine vacuolation of the neuropil (spongiform change) in the deep grey-matter with a slight loss of neurons and gliosis, consistent with CJD.

After a cold in August, 1990, a 53-year-old woman had difficulty sleeping and complained of dizziness. When cycling she found it hard to keep her balance. A neurologist noted trunk and gait ataxia and a tremor of her right thumb. By October she had become forgetful, had difficulty expressing herself, and her speech was
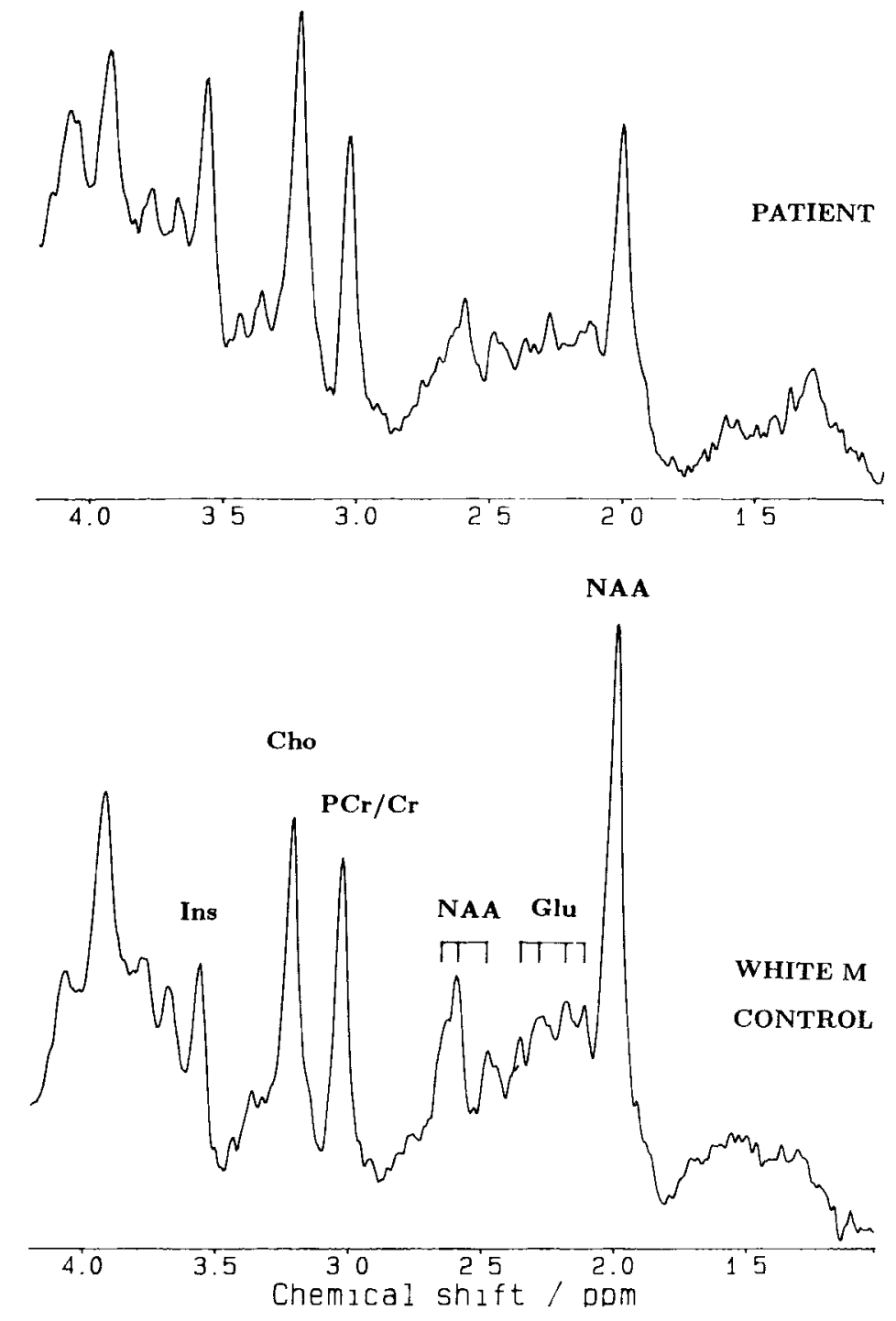

Fig 1-Localised proton MR spectra of parietal white-matter.

Upper: Patient with CJD, exhibitıng reduction of NAA and $\mathrm{PCr} / \mathrm{Cr}$ and increase in Ins.

Lower control

Major metabolites include $\mathrm{N}$-acetylaspartate (NAA), glutamate (Glu), creatine $(\mathrm{Cr})$, and phosphocreatine $(\mathrm{PCr})$, choline-containing compounds (Cho), and myo-inositol (Ins). Volume of interest $12 \mathrm{ml}$

slurred. Nocturnal anxiety and paraspasticity ensued and she was admitted to hospital in November. Her ataxia worsened as did her memory. Paranoid-hallucinatory states required treatment with haloperidol for a week. In December a progressive left-sided spasticity developed. Dysarthria further impeded her speech and she became demented. CSF analysis revealed oligoclonal banding. EEGs revealed diffuse slow and $\alpha$-range complexes with temporooccipital sharp wave $\theta$ and $\delta$-complexes. No 1-2 $\mathrm{Hz}$ periodic sharp wave complexes (PSWC) were seen. In February, 1991, the patient was in a coma and showed spontaneous myoclonus, predominantly in her right arm. An EEG showed PSWCs, supporting the diagnosis of CJD. ${ }^{2}$ In March localised proton MRS was done with $20 \mathrm{~ms}$ echo-time stimulated-echo sequences $(2.0 \mathrm{~T}$ Siemens 'Magnetom'). ${ }^{3}$ Measuring times were $6.5 \mathrm{~min}$ with 128 accumulations and repetition times of $3 \mathrm{~s}$.

Fig 1 shows the proton MR spectrum of the left parietal white-matter of the patient, compared with that of a 56-year-old healthy female control. The $\mathrm{N}$-acetylaspartate (NAA) peak was reduced $(40 \%)$, as was the creatine/phosphocreatine ratio $(10 \%)$; there was an increase in inositol $(30 \%)$. Similar findings were observed contralaterally and in frontal white-matter except for slightly lower values of choline-containing compounds. Two volumes of interest in predominantly grey-matter were investigated in paramedian frontal and parietal locations; only NAA was diminished (30\%) (fig 2). MRS in the hyperintense region of the striatum showed a fourfold loss of metabolites. The remaining metabolite pattern exhibited a further reduction of NAA relative to creatines and cholines. 

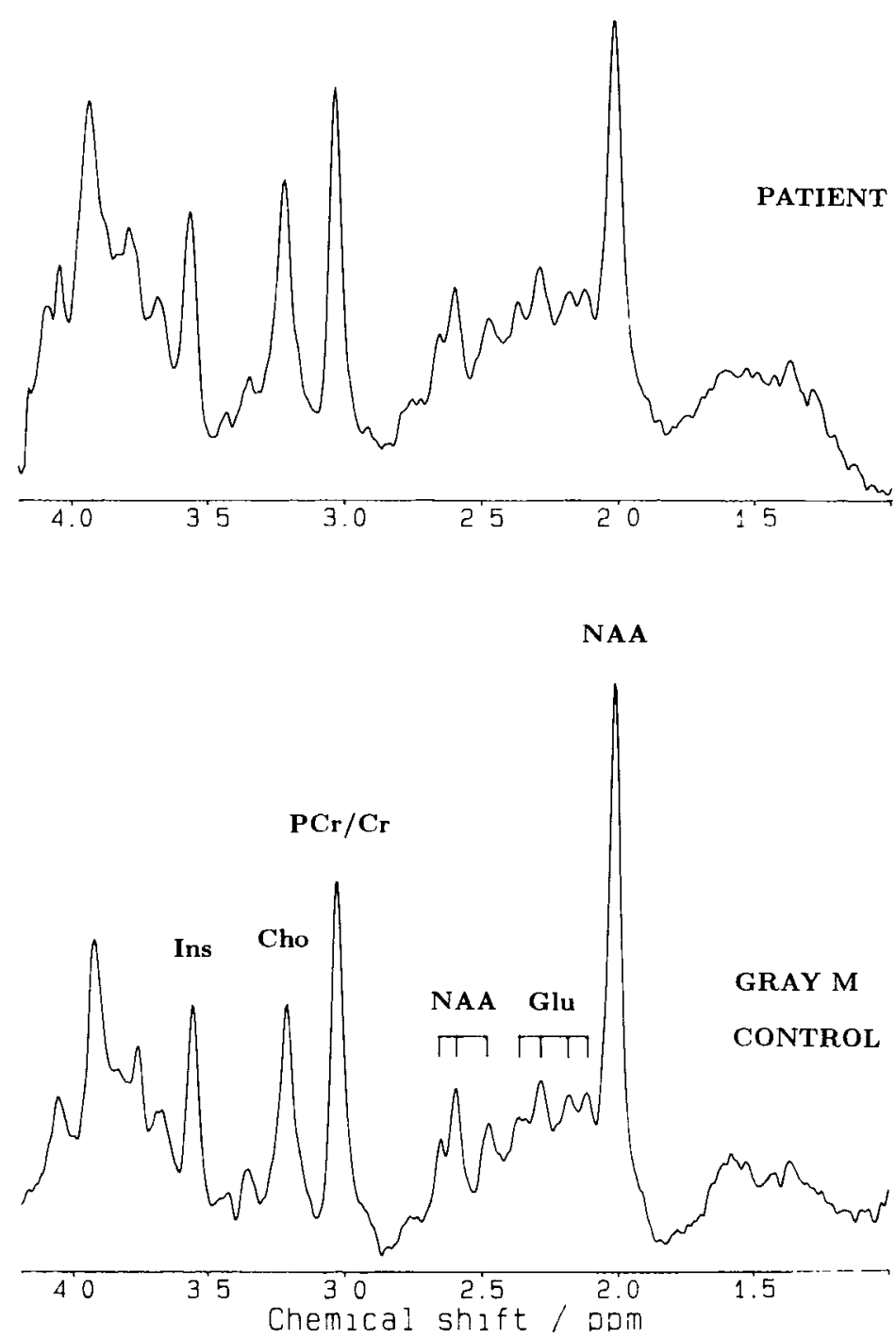

Fig 2-Localised proton MR spectra and paramedian greymatter.

Upper: Patient with CJD exhibiting reduction of NAA. Lower. control. Volume of interest $18 \mathrm{ml}$.

The NAA data, a marker of vital neuronal tissue, ${ }^{4}$ indicate severe neuronal loss in CJD. Most notably, MRS in this patient revealed metabolic alterations in regions of the brain that had appeared normal on magnetic resonance imaging. Structural preservation in the presence of gross functional impairment in CJD is often seen with computerised tomography. Positron emission tomography $y^{5,6}$ reveals hypoperfusion and hypometabolism but proton MRS has the potential advantage of selectively indicating neuronal damage, the cell type most severely affected in the spongiform encephalopathies. This non-invasive investigation could be of use in the early diagnosis of CJD.

Financial support by the Bundesminister für Forschung und Technologie (grant 01 VF 8606/6) is gratefully acknowledged.

Max Planck Instıtute for Biophysical Chemıstry,

D-3400 Gottıngen, Germany,

Neurological Clinic,

University of Gottıngen;

and Klınık Schildautal, Seesen

H. BRUHN

T. WEBER

V. THORWIRTH

J. FraHM

1. Pearl GS, Anderson RE. Creutzfeldt-Jakob disease: high caudate signal on magnetic resonance imaging. South $\mathrm{Med} f \mathrm{f}$ 1989; 82: 1177-80.

2. Levy SR, Chiappa KH, Burke CJ, Young RR. Early evolution and incidence of electrencephalographic abnormalities in Creutzfeldt-Jakob disease. $f$ Clin Neurophystol 1986; 3: 1-21.

3. Frahm J, Michaelis T, Merboldt KD, Bruhn H, Gyngell ML, Hanıcke W. Improvements in localized proton NMR spectroscopy of human brain: water suppression, short echo times, and $1 \mathrm{ml}$ resolution. I Magn Reson 1990; 90: 464-73.

4. Bruhn H, Frahm J, Gyngell ML, Merboldt KD, Hänıcke W, Sauter R. Cerebral metabolism in man after acute stroke: new observations using localized proton NMR spectroscopy. Magn Reson Med 1989; 9: 126-31.

5. Hunter R, Gordon A, McLuskie R, et al. Gross regional cerebral hypofunction with normal CT scan in Creutzfeldt-Jakob disease. Lancet 1989;1.214-15.

6. Holthoff VA, Sandmann J, Pawlik G, Schroder R, Heiss WD. Posttron emission tomography in Creutzfeldt-Jakob disease. Arch Neurol 1990; 47: 1035-38.

\section{High frequency of concomitant pancreatitis in salmonella enteritis}

SIR,-Dr Baird-Parker (Nov 17, p 1231) underscores the increasing incidence of foodborne salmonellosis in many countries of the western world. ${ }^{1}$ We report some observations that are relevant to the clinical picture and differential diagnosis of this diarrhoeal condition.

Stimulated by a case of salmonellosis with severe concomitant pancreatitis we prospectively followed all culture-proven cases of salmonella enteritis for symptoms and laboratory signs of concomitant pancreatitis. Within 18 months we treated 47 patients with salmonella enteritis (17 men; mean age 45 [range 16-79] years). 16 patients had Salmonella typhimurium and 31 had $S$ enteritidis infections, 1 patient having both. The frequency of concomitant pancreatitis as assessed by raised serum amylase and lipase was:

$\begin{array}{lcc} & \text { Concomitant pancreatitis } & \text { No pancreatitis } \\ \text { No } & 29(62 \%) & 18(38 \%) \\ \text { Men/women } & 8 / 21 & 9 / 9 \\ \text { Mean age (range) } & 44 \cdot 8(18-79) & 45 \cdot 8(16-71)\end{array}$

Concomitant pancreatitis was found in 7 patients with $S$ typhimurium and in 22 with $S$ enteritidis $(\mathrm{p}<0.05$, Chi-square test). The course of pancreatitis was usually mild to moderate, with some pancreatic enlargement, as shown by abdominal sonography, in about half the patients. Pancreatitis was unrelated to treatment of salmonellosis either by fluid replacement alone or antibiotics (mainly ciprofloxacin).

The high frequency of concomitant pancreatitis in salmonella enteritis in our series is in contrast with other publications. In gastroenterological textbooks salmonella pancreatitis is not mentioned ${ }^{2}$ or is merely listed in tables. ${ }^{3}$ Only in paediatric publications has some attention been paid to these forms of pancreatitis complicating viral or bacterial infections. ${ }^{4}$ The pathogenetic mechanisms are unknown as far as we are aware. By analogy to other infections, a haematogenous attack on parenchymal pancreatic cells seems probable.

These observations indicate that patients with upper abdominal pain in salmonella enteritis should be investigated for concomitant pancreatitis, and in those with hyperamylasaemia and diarrhoea, salmonellosis should be considered as a possible explanation for this clinical condition.

Department of Medicine,

FRIEDRICH RENNER 4910 Ried/I, Austria

CHRISTIAN NIMETH

Nikolaus Demmelbauer

1. World Health Organisation. Salmonellosis control: the role of animal and product hygiene. WHO Tech Rep Ser 1988, no 774.

2. Soergel KH. Acute pancreatitis. In: Sleisinger MH, Fordtran IS, eds. Gastrointestinal disease, 3rd ed. Philadelphia Saunders, 1983: 1462-84.

3. Creutzfeldt W, Lankisch PG. Acute pancreatitus: etiology and pathogenesis. In: Berk JE, ed. Bockus gastroenterology, 4th ed. Philadelphia: Saunders, 1985. 3971-92.

4. Seifert G. Zur Pathologie der Pankreatitis im Kindesalter. Mschr Kanderheilk 1960; 108: $225-29$

\section{Mega-dose methylprednisolone for chronic idiopathic thrombocytopenic purpura}

SIR,-Dr Balint and colleagues (May 4, p 1106) mention, among other approaches, conventional prednisolone $(1-2 \mathrm{mg} / \mathrm{kg}$ daily) administration for the treatment of idiopathic thrombocytopenic purpura (ITP).

With colleagues, I have shown that such treatment for 2 weeks is not effective in ITP; on the contrary it delays spontaneous recovery in childhood acute ITP. ${ }^{1}$ Mega-dose oral ${ }^{2}$ or intravenous ${ }^{1,3}$ methylprednisolone (MDMP; $30 \mathrm{mg} / \mathrm{kg}$ daily for 3 days followed by $20 \mathrm{mg} / \mathrm{kg}$ for 4 days; each dose given before $0900 \mathrm{~h}$ ) has, however, proved very effective. Platelet counts increased to over $150000 / \mu 1$ within 3 days in about two-thirds of patients. ${ }^{1,2}$ Intravenous MDMP has also been used successfully in children ${ }^{46}$ and adults ${ }^{7,8}$ with chronic ITP. We have used oral MDMP $(30 \mathrm{mg} / \mathrm{kg}$ and 20 $\mathrm{mg} / \mathrm{kg}$ daily, each for 1 week; every dose before $0900 \mathrm{~h}$ ) in 10 children with chronic ITP (ie, duration longer than 6 months). 1 child could not be followed. Platelet count increased to over $150000 / \mu \mathrm{l}$ in 6 patients within 3 days and in 8 by 2 weeks. 